\title{
WHAT KIND OF PROPERTY IS "RELATIONSHIP PROPERTY"?
}

\section{Bill Atkin*}

This article explores the meaning of "property" in the Property (Relationships) Act 1976. The definition of "property" in the Act is a wide one and is fundamental to jurisdiction under the Act. The article surveys the spectrum of legislative definitions of property. Then, with respect to the definition in the 1976 Act and in light of contemporary legislative aims, it is suggested that the meaning of the term should not be shackled by traditional concepts. Some of the leading judgments are examined, including two regarding relationship property from the Supreme Court, and it is found that the courts have already been adventuresome.

\section{INTRODUCTION}

The Property (Relationships) Act 1976 (PRA) is ostensibly about property but its policy goals are about people and the fair division of the property that was central to the couple's life. The definition of "property" in the Act is a wide one and is fundamental to jurisdiction under the Act. ${ }^{1}$ Various key issues have arisen in relation to earning capacity, future income, superannuation, trusts, restraint of trade covenants, and personal effort, among other matters. This has led to a significant body of case law, in effect wrestling with the meaning of property in the Act.

This article first explores the legislative spectrum of definitions of property, and in particular notes a recent Supreme Court judgment, albeit one from the criminal law context. ${ }^{2}$ This judgment reminds us, inter alia, of the fundamental importance of parliamentary purpose or intention. It is then noted that the purpose changed when the PRA was revised in 2001. I thus suggest that, in the

* Professor of Law, Victoria University of Wellington. I especially thank my outstanding research assistant, Sean Brennan. This article was originally prepared for the Private Law Roundtable at VUW, 22-23 February 2016. Since then, the Supreme Court released two significant judgments involving the same parties: Clayton v Clayton [Vaughan Road Property Trust] [2016] NZSC 29, [2016] 1 NZLR 551 and Clayton v Clayton [Claymark Trust] [2016] NZSC 30, [2016] 1 NZLR 590. The first of these is relevant to this article.

1 The allied term "owner" is also defined in s 2 and refers to the beneficial owner. Space does not permit further examination of this term.

2 Dixon v R [2015] NZSC 147, [2016] 1 NZLR 678 [Dixon]. 
light of the contemporary legislative aims, the meaning of the term should not be shackled by traditional concepts. Some of the leading judgments are examined, including two more from the Supreme Court, ${ }^{3}$ and it is found that the courts have already been adventuresome. Scope exists to be even more so.

\section{THE LEGISLATIVE DEFINITION}

\section{A "Property"}

"Property" is a core concept in New Zealand legislation. It is defined in many places, and these definitions vary. This is not surprising given the differing purposes of legislation. The definition in the PRA is at the widest end of the spectrum: ${ }^{4}$

property includes-

(a) real property:

(b) personal property:

(c) any estate or interest in any real property or personal property:

(d) any debt or any thing in action:

(e) any other right or interest.

This definition is effectively the same as that in some other family law statutes such as s 2 of the Child Support Act 1991 and s 2 of the Family Proceedings Act 1980, along with s 2 of the Crimes Act 1961, s 2 of the New Zealand Government Property Corporation Act 1953, s 6 of the Overseas Investment Act 2005, s 4 of the Public Trust Act 2001, and s 2 of the Trustee Act 1956..$^{5}$ A key word common to these definitions is "includes", which implies that the definition does not cover everything: some items of property may fall outside the five categories (as listed in the PRA definition).

A contrast can be drawn with the definition shared by s 2 of the Companies Act 1993 and s 3 of the Insolvency Act 2006:

property means property of every kind whether tangible or intangible, real or personal, corporeal or incorporeal, and includes rights, interests, and claims of every kind in relation to property however they arise.

This definition uses the word "means" and is therefore intended to be exclusive: other categories are excluded, but it then also uses "includes" in the second part of the definition. It adds the phrase

3 Thompson v Thompson [2015] NZSC 26, [2015] 1 NZLR 593; and Clayton v Clayton [Vaughan Road Property Trust] [2016] NZSC 29, [2016] 1 NZLR 551 [Clayton].

4 Property (Relationships) Act 1976, s 2.

5 See also the list in Clayton, above n 3, at n 29. 
"tangible and intangible", and the broad phrase "rights, interests, and claims of every kind" is qualified by the words "in relation to property", which is partly circular and impliedly narrows the impact of the words.

A further contrast can be made with s 4 of the Property Law Act 2007:

property-

(a) means everything that is capable of being owned, whether it is real or personal property, and whether it is tangible or intangible property; and

(b) includes any estate or interest in property; and

(c) in subpart 6 of Part 6, has the extended meaning given to that term in section 345(2)

Section $345(2)$

property includes the proceeds of any property.

This definition is not unlike that in the Companies Act and Insolvency Act, but uses the important phrase "is capable of being owned". A final contrast can be made with another family law statute, the Domestic Violence Act 1995. In s 2 we find this:

property, in relation to a person, means property that-

(a) the person owns; or

(b) the person does not own but-

(i) uses or enjoys; or

(ii) is available for the person's use or enjoyment; or

(iii) is in the person's care or custody; or

(iv) is at the person's dwellinghouse.

The focus in this definition is on ownership or possession, because the powers in the Act are relevant to the protection of the applicant and access to accommodation and furniture. A wider definition, such as that found in the PRA, makes little sense in this context.

\section{B Dixon (with a Mention of Clayton)}

Except for the PRA, there is little judicial exploration of these definitions in New Zealand. However, late in 2015 the Supreme Court considered the definition under the Crimes Act 1961 in the context of a charge of accessing a computer system for a dishonest purpose contrary to $\mathrm{s}$ 249(1)(a). One element of the offence is obtaining, inter alia, any property without claim of right. Dixon $v R$ involved an infamous incident during the 2011 Rugby World Cup when security cameras recorded the English vice-captain leaving a bar with a female patron: Mike Tindal was married to a 
member of the royal family and the event was thus regarded as newsworthy. ${ }^{6}$ An employee of the security company posted footage on a website, resulting in what the Court called "something of a media uproar". ${ }^{7}$ The Court of Appeal held that property as defined in the Act does not cover information including digital data, ${ }^{8}$ but the Supreme Court reversed this.

The Supreme Court did not consider itself in a position to re-assess the "orthodox" view that pure information is not property. So, its judgment is limited to "digital files", accepting the Crown's argument that such files are not "simply information". 9 Interestingly, the Court relied on the famous Australian matrimonial case Kennon v Spry, which concerned a wife's property rights in a trust under the relevant Australian legislation (a topic touched on in Part IVB). Arnold J for the Court cited Gummow and Hayne JJ: ${ }^{10}$

[T] he term "property" is not a term of art with one specific and precise meaning. It is always necessary

to pay close attention to any statutory context in which the term is used.

The Supreme Court, in the context of the Crimes Act, had "no doubt" that the files were property as they could be identified, had a value and were capable of being transferred to others: they had "a physical presence" even though not detectable "by means of the unaided senses". ${ }^{11}$ It did not matter whether they were tangible or intangible. ${ }^{12}$ Later, the Court referred to "the fundamental characteristic of 'property"' of its being "capable of being owned and transferred". ${ }^{13}$ The references to "physical presence" and transferability might be seen as constraints on what is otherwise a wide interpretation of the notion of property. As we see later in Part IIIB, they do not sit well with one of the leading relationship property judgments on the meaning of property.

What are the implications for the PRA? The author is not aware of any judgments where the question of digital files has been the subject of a relationship property claim. On the face of it, Dixon supports the view that electronic material is capable of being property divisible under the Act.

6 Dixon, above n 2.

7 At [2].

8 Dixon $v$ R [2014] NZCA 329, [2014] 3 NZLR 504. The conviction was still upheld for obtaining a "benefit" as opposed to "property" under s 249.

9 Dixon, above n 2, at [24].

10 Kennon v Spry [2008] HCA 56, (2008) 238 CLR 366 at [89] as cited in Dixon, above n 2, at [25].

11 Dixon, above n 2, at [25].

12 At [50] the Court states that this distinction was not a "key question" as the definition in s 2 of the Crimes Act includes both tangible and intangible property. The definition does not actually say this, but, like the PRA definition, it is surely wide enough to cover intangibles.

13 At [38]. 
The issue would then be about the classification of data as "relationship" versus "separate property", and its valuation.

More broadly, Dixon flags several important points for the interpretation of property in a statutory context:

(i) The process of interpretation is an art rather than a precise science. This implies a degree of flexibility but also some imagination in enabling the law to respond to new developments and new legal issues.

(ii) The Court is comfortable with pushing the boundaries of property out beyond common understandings. In relation to digital information, the Court of Appeal was concerned about the effect on freedom of speech, an issue that the Supreme Court did not address. By implication, other interests such as the right to personal ownership and privacy come into play, so that pushing the boundaries of property may have justifiable policy bases. For the spouse or partner, this is the right to an appropriate share of the property produced by or related to the marriage, civil union or relationship.

(iii) The law can accommodate more than one meaning of property. An item may be property and not be property at the same time, depending on the issue at stake. This is obvious from the differing statutory definitions, but it is significantly reinforced by the way in which the Supreme Court reached its conclusion.

(iv) The Supreme Court saw property as being something "capable of being owned and transferred". ${ }^{14}$ This statement was made without any substantial analysis of phrases such as "any other right or interest". We see later in Part III that relationship property case law has not insisted on this requirement.

(v) Finally and importantly for the PRA, the legislative purpose is all important. ${ }^{15}$ Thus, in determining what amounts to property under the PRA, a key driver must be the purposes and principles of the Act. Arguably, a purposive construction of the Act mandates a broad approach to the concept of property.

The specifics of the Supreme Court decision in Clayton $v$ Clayton, relating to trusts and relationship property, are discussed in Part IVB below. ${ }^{16}$ Suffice it to say that the emphasis on the statutory context is reiterated. Because the PRA is social legislation, a broadening of traditional

14 At [38].

15 This of course is provided for by the Interpretation Act 1999, s 5, and s 6 requires that an enactment be applied "to circumstances as they arise". Both sections are cited in Dixon, above n 2, at [33].

16 Clayton, above n 3. 
concepts of property is justified. ${ }^{17}$ Indeed, "worldly realism" means "that strict concepts of property law may not be appropriate", ${ }^{18}$ thus laying the foundation for a bold approach to the treatment of trusts in that case.

\section{Purpose of the Property (Relationships) Act}

In the landmark decision of $Z v Z$ (No 2), discussed in greater depth in the next Part, the Court of Appeal emphasised the importance of "the legislative setting" along with the "social and economic context". ${ }^{19}$ The primary source of the purpose of the original Matrimonial Property Act 1976 was the long title:

... to reform the law of matrimonial property; to recognise the equal contribution of husband and wife to the marriage partnership; to provide for a just division of the matrimonial property between the spouses when their marriage ends by separation or divorce.

With the extensive reforms enacted in 2001, including the change of name of the Act to the somewhat awkward Property (Relationships) Act 1976, two new sections set out the purpose and the principles of the Act. ${ }^{20}$ They embellish what was in the original Act and add highly important references to economic disadvantage.

Section $1 \mathrm{M}$ reads:

Purpose of this Act

The purpose of this Act is-

(a) to reform the law relating to the property of married couples and civil union couples, and of couples who live together in a de facto relationship:

(b) to recognise the equal contribution of both spouses to the marriage partnership, of civil union partners to the civil union, and of de facto partners to the de facto relationship partnership:

(c) to provide for a just division of the relationship property between the spouses or partners when their relationship ends by separation or death, and in certain other circumstances, while taking account of the interests of any children of the marriage or children of the civil union or children of the de facto relationship.

17 At [38].

18 At [79].

$19 Z \vee Z$ (No 2) [1997] 2 NZLR 258 (CA) at 264 and 267.

20 Property (Relationships) Act 1976, ss 1M and 1N. The title of the legislation was borrowed from legislation of that name in New South Wales (1984). 
Section $1 \mathrm{~N}$ reads:

\section{Principles}

The following principles are to guide the achievement of the purpose of this Act:

(a) the principle that men and women have equal status, and their equality should be maintained and enhanced:

(b) the principle that all forms of contribution to the marriage partnership, civil union, or the de facto relationship partnership, are treated as equal:

(c) the principle that a just division of relationship property has regard to the economic advantages or disadvantages to the spouses or partners arising from their marriage, civil union, or de facto relationship or from the ending of their marriage, civil union, or de facto relationship:

(d) the principle that questions arising under this Act about relationship property should be resolved as inexpensively, simply, and speedily as is consistent with justice.

These two sections, inter alia, emphasise equality, the variety of contributions that people make, and differing economic positions. They relate to personal relationships of the kind that, by the 2001 Amendment Act, fall within the jurisdiction of the PRA - marriages, civil unions (from 2005), and de facto relationships, including those that have ended through separation or death. This is to be contrasted with ordinary commercial dealings where the parties are typically treated as strangers, and where notions of equality, contributions over a period of years, and financial disparities are irrelevant. The Act is primarily concerned with fair outcomes for the parties themselves, and does not directly impinge on the conventional rights of third parties. ${ }^{21}$ In the words of Woodhouse $\mathrm{J}$ in one of the early leading judgments, Reid $v$ Reid, the statutory scheme is "social legislation" of the widest general application, "not a part of the law of property in any traditional sense".22

In a broader sense the PRA is described as a "deferred community" regime. ${ }^{23}$ This means that, for the most part, ordinary rules of legal and beneficial title apply during the course of a relationship, as expressly provided for in s 19 , but at the end of the relationship, the concept of "community" comes into play. Relationships are regarded as partnerships or a form of community, but the effect on property division is deferred until the relationship ceases. At this point it becomes

21 Phenomena such as the ability of a person upon whom the parties make conflicting claims and of the Official Assignee to claim under the Act can be ignored as atypical: Property (Relationships) Act 1976, s 23.

22 Reid $v$ Reid [1979] 1 NZLR 572 (CA) at 580 and see also 610 per Richardson J. This case went to the Privy Council where the Court of Appeal was upheld: Reid $v$ Reid [1982] 1 NZLR 147 (PC). The points are reiterated in $Z \vee Z$ (No 2), above n 19, at 263 .

23 For a fuller discussion of this see AH Angelo and WR Atkin "A Conceptual and Structural Overview of the Matrimonial Property Act 1976" (1977) 7 NZULR 237. 
crucial to know which property is "relationship property", to be divided according to the rule of equal division and which is "separate", usually kept outside the jurisdiction of the Act. A close examination of ss $8-10$ reveals that, in summary terms, relationship property is what may be described as the product of the parties' living together, along with core family property, the home and chattels.

One of the big questions is how all this affects the concept of property in the Act. A narrow reading reduces the amount of property that is available for division under the Act and may thus compromise the Act's goals. This is most likely to work to the disadvantage of women, although this may be a little less true in 2016 than in 1976 when the levels of female employment were lower. A broad reading expands the pool available for division, thus supporting the Act's goals. On the other hand, where the extra assets are not liquid or easily converted into a liquid form, the owner may be left in a precarious position, having to find ways of satisfying the other party's interests.

The judicial approach under the PRA has been to the middle of this spectrum but with a broader rather than a narrower interpretation. Could it have been wider, especially in the light of the principles as articulated in 2001 ?

\section{III $\quad \mathrm{Z} \vee \mathrm{Z}$ (NO 2)}

\section{A The Effect of the Judgment - Earning Capacity}

The foundational judgment to grapple with the meaning of property under the PRA is $Z v Z$ (No 2). ${ }^{24}$ This is not to be confused with a different Court of Appeal case, also called $Z v Z$, which related to the valuation of goodwill in a sole practice law firm. ${ }^{25}$ Sir Ivor Richardson, the President, was no doubt influenced by the Royal Commission on Social Policy that he had chaired and that was cited in the judgment in establishing "the inequality of equal division": while property was divided equally in a formal sense, the parties were left in unequal positions because the husband left the marriage in a far better income earning position that the wife. ${ }^{26}$ The interplay between capital and income is one of the key themes of the law on financial division between ex-partners. While prima facie capital and property are dealt with by the PRA and income is covered by the maintenance rules in the Family Proceedings Act 1980, the distinction turns out to be much murkier than this. $Z v Z$ (No 2) illustrates the point.

$24 Z v Z$ (No 2), above $\mathrm{n}$ 19. This case was decided under the Matrimonial Property Act 1976 before the 2001 reforms.

$25 Z v Z[1989] 3$ NZLR 413 (CA).

$26 Z v Z$ (No 2), above n 19, at 275 and 277. See The April Report: Report of the Royal Commission on Social Policy (Wellington, April 1988) vol 4 at 18-19 and 217-227. Following the 2001 amendments, the comment can be extended to de facto partners, and later to civil unions. 
A marriage of 28 years ended. The three children were grown up and the wife had health problems affecting her ability to develop a late career. The husband had been very successful in the public service and then as a partner in a large international accountancy firm. While he commanded over $\$ 300,000$ per annum, the wife was largely restricted to a social security benefit of $\$ 7000$ per annum (although the husband had also been ordered to pay interim maintenance of $\$ 1200$ per month). Other matrimonial property was worth $\$ 900,000$. The discrepancy in income potential was the glaring feature of the marriage: the husband's vastly better position was established during the course of the marriage and can be said to be a product of the marriage. Yet, how could the wife share in it? The maintenance laws are designed to provide a person with temporary relief based on need and an inability to be self-supporting, a far cry from the equal division rule in the PRA. The wife therefore argued that the husband's enhanced earning capacity was property capable of being valued and divided between the two of them.

\section{B The Effect of the Judgment - Earning Capacity and Super Profits}

The Court of Appeal rejected the wife's primary argument but found what at the time was an unexpected solution for the wife.

The Court found the wife's arguments very compelling but concluded that to treat enhanced earning capacity as property "would be a radical departure from the conventional concept which Parliament chose to endorse". ${ }^{27}$ It could not even come within the beguiling words "any other right or interest" in s 2 nor other notions allowed for by the word "includes". One of the main reasons for the decision was a distinction drawn between property and entirely personal characteristics, earning capacity falling within the latter. ${ }^{28}$ It is easy to understand how something like beauty would be hard to consider as property, even if it is central to the career of someone such as a model. Likewise, intelligence and the physical skills of an athlete are hard to see as property. Earning capacity was therefore regarded by the Court in the same light: human capital rather than property in the legal sense, which Parliament had not intended to include within the Act. This is despite the fact that $\mathrm{Mr}$ Z's healthy position had a great deal to do with his wife's support, her work in the home and her rearing of the children, freeing him to focus on his career.

The Court then gave the wife a lifeline. Under the Act, property does not have to be transferable or have an exchange value. ${ }^{29}$ It can be intangible and need not be something that is usually bought and sold. While earning capacity as such is not property, it may indirectly be so if "harnessed through an external mechanism". ${ }^{30}$ The Court then set its sights on the husband's partnership

$27 Z \vee Z$ (No 2), above n 19, at 281.

28 At 264 .

29 At 282. This is contrary to the Supreme Court in Dixon, above n 2, as discussed in Part II.

$30 Z v Z$ (No 2), above n 19, at 282. 
interest, although it tantalisingly also floated the possibility that a sole practice or even an employment contract might provide the necessary mechanism. ${ }^{31}$

Under Mr Z's partnership agreement, a partner's goodwill was treated as worth zero. However, partners were entitled to a retirement benefit. This did not fall within the definition of superannuation under the Act, but was held to be part of the "bundle of rights" that nevertheless formed a partner's interest in the firm. ${ }^{32}$ Although the benefit was not related to any contributions nor tied to employment as superannuation policies often are, it could be valued and divided. ${ }^{33}$ Quite apart from this, a partner had an interest in the partnership that was valuable and not dependent on dissolution of the firm. This went beyond the partner's own personal input and related to the income stream and access to clients that came with membership of the firm. Labelled "super profits" and treated as part of the bundle of rights, they are surely better treated as an independent item of property. They relate very much to the future and the future flow of earnings and they are about earning capacity that is not dependent solely on personal characteristics. They can be categorised as either relationship or separate property and be valued. While this appears to give Mrs Z a share of future income, the Court was careful to categorise the husband's interest as "the present value of future earnings" and to reject a valuation based on the capitalisation of future earnings up to retirement. $^{34}$

The issue of valuation is crucial. While the Court of Appeal offered some advice, the matter was ultimately remitted to the High Court. In a subsequent decision in $M v B,{ }^{35}$ the Court emphasised the variety of factors that may influence the valuing of super profits, in that case in a law firm: the person's age, whether there was a right to any residual capital payout, the kind of work (as the firm had a Crown Warrant, there was a secure ongoing income stream but probably at a lesser level than other firms), and the degree of capture by the firm, that is, the restricted nature of the firm's work may reduce the ease with which the person can find another job). Scott $v$ Williams involved a very small law firm with two partners, not far removed from the sole practice that the Court mentioned in passing in $Z \vee Z$ (No 2). ${ }^{36}$ Faire $\mathbf{J}$ upheld the Family Court judge's calculation of over \$1 million and

31 At 283

32 At 284

33 Haldane v Haldane [1981] 1 NZLR 554 (CA) is the leading decision on superannuation and valuation of such policies.

$34 Z v Z$ (No 2), above $\mathrm{n} \mathrm{19}$, at 288 and 291 (emphasis added).

$35 M v B$ [2006] 3 NZLR 660 (CA).

36 Williams $v$ Scott [2014] NZHC 2547, [2015] NZFLR 355; and Scott $v$ Williams [2016] NZCA 356, [2016] NZFLR 499. Faire $\mathbf{J}$ took the super profits into account in reducing the Family Court judge's award of economic disparity of $\$ 850,000$ to $\$ 280,000$. However, the Court of Appeal disagreed, and awarded $\$ 470,000$ economic disparity compensation. 
this was in turn upheld by the Court of Appeal. This appears to be a very large sum and was based on actual income post-separation.

\section{Can Z v Z (No 2) be Revisited?}

The decision in $Z \vee Z$ (No 2) can be seen as adopting a broad approach to the meaning of property but not one that pushes the boundaries as far as it might. Its decision to reject enhanced earning capacity as an item of property was mitigated by its acceptance of super profits as property. Strictly speaking super profits are an item that can exist at the date of separation and are not unlike the contingent benefits of a superannuation policy. ${ }^{37}$ In reality they are valuing something that relates essentially to future entitlements: the capital versus income and the present versus future lines of distinction are blurred.

Mrs Z must have been pleased with her result. Yet not everyone will be in her position. By and large, the super profits approach will benefit the professional and richer sections of the community. Many parties who have helped to enhance their partner's career will fall outside this category. Although the Court of Appeal toyed with the idea of its reasoning being applied to employment contracts, it is hard to see how super profits or something similar can apply to the regular wage and salary earner.

So, the $Z \vee Z$ (No 2) solution has its limitations. Can we revisit the decision? Not long afterwards, Parliament made substantial changes to the Act - the 2001 reforms. The Court of Appeal was influenced by what it regarded as Parliament's intention when the Matrimonial Property Act 1976 was passed. Does the 2001 package represent a shift in legislative purpose? Does any such shift alter the reasoning on earning capacity as property? Arguably it does.

As noted above in Part IIC, Parliament in 2001 introduced ss $1 \mathrm{M}$ and $1 \mathrm{~N}$ of the PRA. While the 2001 package was designed to extend the law to de facto relationships and widowed parties, another important change was to address financial disadvantage. This was one of the things that featured in the report of the Royal Commission on Social Policy, discussed above, but also weighed heavily with the Court of Appeal. The decision on earning capacity was driven in large part by the lack of parliamentary intention to depart radically from the conventional meaning of property, but the decision on super profits was doubtless motivated by the desire to do something about "the inequality of equal division". In 2001 the parliamentary purpose changed to include economic advantage and disadvantage. Admittedly this is evidenced by (c) in the principles section, as opposed to the purpose section, but there can surely be no doubt that the principles help to articulate the purpose of the Act, and indeed are explicitly designed "to guide the achievement of the purpose of this Act". ${ }^{38}$

37 Haldane, above $\mathrm{n} 33$.

38 Property (Relationships) Act 1976, s 1N. 
The main tool introduced to deal with economic disadvantage is the new power given to the courts to award compensation for economic disparity. Sections 15 and $15 \mathrm{~A}$ are the source of this power, although s $15 \mathrm{~A}$ is very rarely used and can be ignored for present purposes. Under s 15 , a party may seek compensation if their income and living standards are likely to be significantly lower than those of their ex-partner and this difference is caused by "the effects of the division of functions" during the time when they lived together. An award of compensation does not turn on the classification of enhanced earning capacity or loss of career opportunities as property. On the other hand, there must be sufficient relationship property to cover the amount awarded: compensation under s 15 (as opposed to s 15A) can come only from the respondent's share of relationship property and not from that party's own separate property.

The power to award economic disparity compensation is very significant and has led to a lot of litigation. ${ }^{39}$ It was certainly not a token gesture by Parliament. Along with the changes effected by ss $1 \mathrm{M}$ and $1 \mathrm{~N}$, it represents a fresh approach to property division, while still maintaining the original structure and ethos of the scheme. It could be argued that it is actually Parliament's answer to the problem of income disadvantage and there is now no need to revisit the classification of enhanced earning capacity. This line of argument would be a mistake.

First, the new purpose and principles, as in any other statute, are designed to be a touchstone for the whole Act, not just a part of it. Secondly, ss 15 and 15A deal with disparities but nothing suggests that other provisions are not also to have this aim. The 1988 Working Group considered the issue of real equality post-separation and made several recommendations, the s 15 approach not being one of them. ${ }^{40}$ Widening the property pool and restricting the exceptions to the equal division rule are examples of steps that can also be taken to help achieve substantive, not just formal, equality. The determination of what is property should definitely be influenced by the principle about economic advantage and disadvantage. Thirdly, s 15 is not a panacea. The jurisdictional hurdles - especially the causal nexus between the division of function and the disparities of income and living standards - are not all that easy to surmount. At one stage the author analysed applications for compensation and found that the success rate was about half. ${ }^{41}$ Furthermore, the courts have been much more sympathetic to a claim that the applicant has suffered a loss of career

39 The leading case is $X \vee X$ [Economic disparity] [2009] NZCA 399, [2010] 1 NZLR 601. See also recent judgments in Williams, above n 36; and the somewhat unsatisfactorily reasoned Jack v Jack [2014] NZHC 1495 (this case was settled before the appeal to the Court of Appeal was heard).

40 Report of the Working Group on Matrimonial Property and Family Protection (Department of Justice, 1988). Margaret Wilson was a member of the Working Group and later was the Minister who shepherded the 2001 reforms through Parliament. The author was also a member of the Group.

41 B Atkin "The Disparity in Economic Disparity The need for a full-scale overhaul of ss 15 and $15 \mathrm{~A}$ and maintenance" in New Zealand Law Society Family Law The New Era - Professionalism in the Family Court (NZLS, Wellington 2005) at 212. 
prospects as opposed to a claim that the other party's earning capacity has been enhanced. ${ }^{42}$ This makes the question of whether earning capacity is an item of property much more acute, not one facing the s 15 hurdles. The existence of s 15 does not render this question otiose.

As mentioned, the Court of Appeal in $Z v Z$ (No 2) considered itself constrained by its view of the parliamentary intention. The argument now is that the intention changed in a significant way with the 2001 package of reforms. The change justifies a more radical approach, treating enhanced earning capacity as property. This does not mean that claims can be made about beauty, intelligence, and sporting prowess. These things are truly personal. Enhanced earning capacity however can be the result of the combined efforts of a couple and can be property even though it is not usually something that can be transferred or bought and sold. Admittedly there may be some issues in determining whether earning capacity is truly related to those combined efforts. In some instances, as is also apparent with superannuation, only a portion may properly be regarded as relationship property. These tasks are however not ones beyond the wit or experience of the courts.

Furthermore, it is not now to be perceived as something alien to valuation: ironically, the recent history of valuing compensation for economic disparity, the details of which are beyond this article, involves just such an exercise. It has been a fraught exercise but not an impossible one.

In summary, the ground has shifted quite considerably since $Z v Z$ (No 2) was decided. Fewer objections to treating earning capacity as property can now be raised and indeed the policy arguments point even more firmly towards a different result. As with the Supreme Court's approach to digital data under the Crimes Act, discussed in Part IIB,${ }^{43}$ the wide definition of property in $\mathrm{s} 2$ can be the vehicle for widening the pool of relationship property, not narrowing it.

\section{THOMPSON AND CLAYTON}

\section{A Restraint of Trade Covenants as Property}

The judicial approach in two other recent Supreme Court judgments supports the broad interpretation of property argued for in this article. ${ }^{44}$

Thompson is about a restraint of trade payment. In the ordinary course, if paid during cohabitation, such a payment would not provoke much excitement but in this instance it was paid several years after the parties separated when a lucrative health food business was sold. The business was actually owned by a trust, but the Supreme Court upheld the Family Court finding that the parties had agreed that the trust assets were relationship property. The business was sold for $\$ 72.3$ million, of which $\$ 49.4$ million represented goodwill and \$22.9 million assets. In addition, the

42 See for example Scott v Williams [2016] NZCA 356, [2016] NZFLR 499.

43 Though not its reference to "capable of being owned and transferred", mentioned in Part IIB above.

44 Thompson, above n 3; and Clayton, above n 3. 
husband was paid $\$ 8$ million under a restraint of trade agreement. The nub of the case was about this payment. Was it something that could be said to relate to the marriage or was it in effect a payment reflecting the husband's personal skills, abilities and performance, impacting on his future earning capacity? Was it property that was in effect in existence at the date of separation, the date at which the shares in property are to be determined $?^{45}$

Loosely speaking, a restraint of trade payment is about a person's future conduct: it restrains the person from competing. If paid post-separation, it is prima facie hard to see how it is an item of property of which the ex-partner can be entitled to a share. Such an approach has the virtue of keeping the capital of the relationship separate from future earnings, which, as already seen, has been a matter of considerable controversy. This was essentially the approach of the Court of Appeal. ${ }^{46}$ The Supreme Court reversed that decision and held that the restraint of trade payment was property that existed at the date of separation. In essence the payment was tied up with the valuation of the business for the purposes of sale. Its goal was to protect the goodwill in the business and it was not a form of compensation for loss of future earnings. As the business existed at the date of the separation, so did any right to a restraint of trade payment, even if the payment was made in the future and even if it was about future conduct. The Supreme Court cited both $Z v Z$ and $Z v Z$ (No 2) favourably. ${ }^{47}$ In relation to the latter, an analogy can be made with super profits: although they are about access to future income, they are a property right that exists in the present (or more accurately, at the date of separation). So, the restraint of trade payment can be seen as a mechanism for harnessing a person's income capacity (by restraining competition), not as a payment for flair or other personal characteristics. As such, it is property.

Thompson, in terms of its facts, can hardly be seen as remedying economic disadvantage. Mrs Thompson was already getting \$36 million as her half-share from the sale of the business. In a broader sense however, it fits with the goal of widening the relationship property base. In smaller money cases where sums are paid that have a future element, the categorisation of the payment as an item of property at the date of separation may make quite a difference to outcomes.

\section{B Control of Trusts}

The second case, Clayton, provides a contrast. ${ }^{48}$ There, the difference between what Mr Clayton conceded and what Mrs Clayton claimed was enormous. Mr Clayton was happy for Mrs Clayton to

45 Property (Relationships) Act 1976, s 2F(1)(b).

46 Thompson v Thompson [2014] NZCA 117, [2014] 2 NZLR 741.

$47 Z \vee Z$, above $\mathrm{n} 25$; and $Z \vee Z$ (No 2), above $\mathrm{n}$ 19. The former held that, in valuing a law practice, the likelihood of a restraint of trade payment was to be taken into account.

48 Clayton, above n 3. The Court of Appeal judgment is Clayton v Clayton [2015] NZCA 30, [2015] 3 NZLR 293. See Jessica Palmer and Nicola Peart "Clayton v Clayton: a step too far?" (2015) 8 NZFLJ 114 for vigorous criticism of the Court of Appeal's judgment. The case was settled after the hearing before the Supreme Court: Hamish Fletcher "Costly split: \$28 million divorce case settles" (18 December 2015) Stuff 
have the home and chattels valued at $\$ 850,000$ plus a sum of $\$ 30,000$ already paid, in total a fairly modest amount. However, if the business were included, by Mrs Clayton's calculations she would get half of the relationship property pool of $\$ 28,831,000$. This would have a significant impact on economic advantage and disadvantage. The trouble was that the business was tied up in various trusts, which cannot directly be the subject of division under the PRA. The interaction between trusts and relationship property claims may be described as the supreme problem de jour. This exercised the 1988 Working Group and more recently the Law Commission. ${ }^{49}$

This is not the place to explore all the tensions in relation to this problem. The Clayton litigation explores a raft of issues concerning trusts, including powers in the PRA added in 2001 to award compensation for transfers to trusts, ${ }^{50}$ sham and illusory trusts, ${ }^{51}$ and the power under s 182 of the Family Proceedings Act 1980 to review settled property. ${ }^{52}$ The focus here is on the ruling that the husband's role in relation to the trusts was property, falling within the final words in the statutory definition of property: "any other right or interest". 53

There were several trusts involved in the case but the Vaughan Road Property Trust, the main vehicle for the business, is relevant for our purposes. The husband, wife and the children were beneficiaries. The Court of Appeal had noted that the husband had a power to appoint and remove beneficiaries and trustees. This power was not conferred upon him as a trustee but as "Principal Family Member" under the trust deed. The Court of Appeal was of the view that these powers of appointment were granted in a personal capacity and not subject to fiduciary duties. Further, the husband could, the Court reasoned, appoint himself as sole beneficiary. The husband's powers could be fitted within the PRA definition of property. ${ }^{54}$ The Supreme Court held that the Court of Appeal's analysis was in error because it ignored the fiduciary duties owed to final beneficiaries. Despite this, the Supreme Court effectively reached the same conclusion when it considered the range of powers that the husband had under the trust, including the ability to pay all the trust capital

<www.stuff.co.nz>. The Supreme Court nevertheless delivered two judgments because of the public importance of the issues in the case, following the procedure laid down in Osborne $v$ Auckland Council [2014] NZSC 67, [2014] 1 NZLR 766. The second judgment is not relevant to this article: Clayton $v$ Clayton [Claymark Trust] [2016] NZSC 30, [2016] 1 NZLR 590 [Clayton (SC No 2)]. See further on the Clayton litigation: Nicola Peart "The Property (Relationships) Act 1976 and Trusts: Proposals for Reform" (2016) 3 VUWLR 443.

49 Report of the Working Group on Matrimonial Property and Family Protection, above n 40; and Law Commission Review of the Law of Trusts: Preferred Approach (NZLC IP31, 2012) especially at ch 12.

50 Property (Relationships) Act 1976, ss 44A-44C, and for companies ss 44D-44F.

51 Issues that the Supreme Court ultimately left undecided in Clayton, above n 3.

52 Clayton (SC No 2), above n 48, dealt with s 182.

53 Property (Relationships) Act 1976, s 2.

54 Clayton (SC No 2), above n 48, at [100] and [111]. 
to himself and thus exclude final beneficiaries. The "combination of powers and entitlements" amounted to a general power of appointment, which could be treated as property under the PRA definition. ${ }^{55}$ The Court then concluded that the property was relationship property to be divided equally under the Act. On the question of valuation, Jessica Palmer and Nicola Peart had severely criticised the Court of Appeal for not explaining why the interest equated to the whole of the trust's net assets rather than a portion or an amount discounted for contingencies. ${ }^{56}$ However, the Supreme Court accepted that the property interests equated to the value of the assets of the trust: Mr Clayton had the power to pay himself the whole of these assets, giving him "virtually absolute control". ${ }^{57}$

Clayton heralds a radical approach to the treatment of trust interests and the definition of property. The ruling is consistent with the PRA's goal to reflect the equal contributions of the parties and to address economic disadvantage. A result that left \$28 million effectively in the husband's control and excluded the wife is arguably unfair because of the wildly differing economic positions that the parties are left in. It would also have been out of sympathy with the ground-breaking judgment of the UK Supreme Court in Prest $v$ Petrodel ${ }^{58}$ In that case, a vast amount of property was tied up with the husband's companies. The husband engaged in "persistent obstruction and mendacity", which obviously did not endear him to the Court. ${ }^{59}$ This however was not enough to lift the corporate veil. Despite this, the Court was able to find that the companies' assets were beneficially owned by the husband by way of resulting trust. A court order could therefore, at least in theory, be made directly against those assets. Lord Sumption referred to "claims for ancillary financial relief in matrimonial proceedings, which have some important distinctive features" and said: ${ }^{60}$

There is a public interest in the proper maintenance of the wife by her former husband, especially (but not only) where the interests of the children are engaged. Partly for that reason, the proceedings although in form adversarial have a substantial inquisitorial element. ... [J]udges exercising family jurisdiction are entitled to draw on their experience and to take notice of the inherent probabilities when

55 Clayton, above n 3, especially at [68] and [80]. The Court does not use the phrase "bundle of rights" in this context, though that phrase appears in [4] and [13]. Arguably the phrase "combination of powers and entitlements" is similar to "bundle of rights". Among the overseas judgments that are cited is the High Court of Australia decision in Kennon, above n 10, where a property interest was found in the husband's power to appoint the capital to his wife and her rights as a beneficiary. The facts of Clayton, where the husband could act to his own advantage, were regarded as "far more compelling": Clayton, above n 3, at [73]. See also Frances Gush "The 'bundle of rights' - Unravelling trust principles?" (2012) 7 NZFLJ 157.

56 Palmer and Peart, above n 48, especially at 116 and 117.

57 Clayton, above n 3, at [104] and [105].

58 Prest v Petrodel Resources Ltd [2013] UKSC 34, [2013] 2 AC 415.

59 At [43].

60 At [45]. See also at [85] per Lady Hale. 
deciding what an uncommunicative husband is likely to be concealing. I refer to the husband because the husband is usually the economically dominant party, but of course the same applies to the economically dominant spouse whoever it is.

While these dicta relate in particular to evidence, they are redolent of the underlying policy of ensuring that the party who is less well-off financially is not left stranded.

However, can it be argued that the facts in Clayton were somewhat special and the decision can easily be distinguished in other situations ${ }^{61}$ How much turns on the precise terms of the trust in that case? The facts were of course crucial but this does not mean that underlying concepts cannot be discerned to assist judges and practitioners in other situations. Already noted above in Part IIB is the expansive approach that the Supreme Court is currently adopting to the interpretation of property, especially in the light of the statutory context. In addition, the Court in Clayton referred favourably to "a substance over form approach". ${ }^{62}$ This means that, in other trust cases where the cards are not stacked so much to the advantage of a Mr Clayton, judges should not be too beguiled by the niceties of the trust structure but should be willing to ask what the reality of the situation is, using a dose of "worldly realism", to use a phrase already quoted. ${ }^{63}$ Arguably, what is being looked for is a sufficient "degree of control ... that it is appropriate to classify" the powers and rights as property. ${ }^{64}$

In short, Clayton, all the more so when placed alongside the similar ethos apparent in the second Clayton judgment dealing with postnuptial settlements (and not discussed here), is highly indicative of the Court's generous approach to relationship property and trusts issues. ${ }^{65}$ Its treatment of property more generally is broad, not strict.

\section{CONCLUSION}

Lord Sumption in Prest stated that "Courts exercising family jurisdiction do not occupy a desert island in which general legal concepts are suspended or mean something different". 66 This is a timely word of caution: relationship property law cannot launch out on a frolic of its own. That said, an overly restrictive approach to what constitutes property can shackle the operation of the PRA. In general, the courts have been willing to take risks, for instance with respect to super profits,

61 Nicola Peart asks some telling questions in her article: Peart, above n 48.

62 Clayton, above n 3, at [75].

63 At [79]. See above Part IIB.

64 At [50]. See also [76] and [105] where "control" language is used.

65 Clayton, above n 3.

66 Prest, above n 58, at [37]. 
restraints of trade and trust interests. Arguably such adventuresome interpretations of property are now possible without landing on a desert island. 